\title{
Loyalitas Karyawan ditinjau dari Kualitas Kehidupan Kerja pada Karyawan dan Karyawati
}

\section{Employee Loyalty in terms of the Quality of Work Life for Employees and Employees}

\author{
Edwin Lau*, Rianda Elvinawaty* \& Ahmad Irvan Dwi Putra* \\ Program Studi Psikologi, Fakultas Psikologi, Universitas Prima Indonesia, Indonesia \\ Diterima: Mei 2019; Disetujui: Juli 2019; Dipublish: Agustus 2019
}

*Coresponding Email: win2lau@gmail.com, rianda@unprimdn.ac.id, musisi059@gmail.com

\begin{abstract}
Abstrak
Fokus penelitian ini adalah hubungan antara kualitas kehidupan kerja dengan loyalitas karyawan pada karyawan dan karyawati di PT. Indako Trading Coy, Medan. Tujuan penelitian ini adalah mengetahui dan menganalisis hubungan antara kualitas kehidupan kerja dengan loyalitas karyawan pada karyawan dan karyawati PT. Indako Trading Coy di Medan. Metode dalam penelitian ini adalah kuantitatif. Hipotesis penelitian ini adalah adanya hubungan positif antara kualitas kehidupan kerja dengan loyalitas karyawan. Teknik pengumpulan data yaitu menggunakan teknik pembagiaan skala dimana terdapat pembagian skala untuk mengukur kualitas kehidupan kerja terhadap loyalitas karyawan. Jenis skala yang digunakan adalah Skala Likert. Hasil Penelitian ini adanya hubungan positif antara kualitas kehidupan kerja dengan loyalitas karyawan pada karyawan dan karywati di PT.Indako Trading Coy Medan dengan korelasi Product Moment (r) sebesar 0,626 dengan p sebesar 0,000 ( $p<0,05$ ), artinya semakin tinggi kualitas kehidupan kerja maka semakin tinggi juga loyalitas karyawan, sebaliknya jika semakin rendah kualitas kehidupan kerja, maka semakin rendah pula loyalitas karyawan.
\end{abstract}

Kata Kunci: Kualitas Kehidupan Kerja. Loyalitas Karyawan

\begin{abstract}
.
The focus of this research is the relationship between quality of work life with employee loyalty to employees at PT. Indako Trading Coy, Medan. The purpose of this study was to determine and analyze the relationship of quality of work life with employee loyalty to employees at PT. Indako Trading Coy, Medan. The method in this research is quantitative. The research hypothesis is that there is a positive relationship between the quality of work life and employee loyalty. Data collection techniques are using scale techniques where there is a scale distribution to measure the quality of work life towards employee loyalty. The type of scale used is the Likert Scale. The results of this study are a positive relationship between the quality of work life and employee loyalty to employees and employees at PT. Indako Trading Coy Medan with a Product Moment correlation ( $r$ ) of 0.626 with $p$ of $0.000(p<0.05)$, meaning the higher quality of life work, the higher the loyalty of employees, on the contrary if the lower the quality of work life, the lower the loyalty of employees.
\end{abstract}

Keywords: Quality of Work Life, Employee Loyalty

How to Cite: Edwin, R. Elvinawaty, \& A.I.D Putra. (2019). Loyalitas Karyawan ditinjau dari Kualitas Kehidupan Kerja pada Karyawan dan Karyawati. Journal of Education, Humaniora and Social Sciences (JEHSS). 2 (1): 12-23.

\section{PENDAHULUAN}

Era globalisasi telah bergulir, dominasi teknologi informasi sebagai infrastruktur menjadi sahabat para pelaku bisnis. Ekonomi akan lebih berbasis pada pengetahuan, bukan tanah, atau mesin-mesin tradisional. Aset ekonomi semakin tidak lagi bersifat fisik, seperti gedung, mesin atau properti lainnya, tetapi bersifat mental intelektual, 
seperti persepsi pasar, hubungan, citra perusahaan, citra merek, hal paten, kredibilitas, visi dan pengetahuan khusus. Senamo, dalam (Sutrisno,2016).

Persaingan antar perusahaan di era globalisasi semakin tajam. Sehingga sumber daya manusia (SDM) atau yang biasa disebut sebagai karyawan dituntut untuk terus menerus mampu mengembangkan diri secara proaktif. Sumber daya manusia (SDM) harus menjadi manusia-manusia pembelajar, yaitu pribadi-pribadi yang mau belajar dan bekerja keras dengan penuh semangat, sehungga potensi insaninya berkembang maksimal (Sutrisno, 2016)

Tujuan tersebut tidak mungkin terwujud tanpa peran aktif karyawan meskipun alat-alat yang dimiliki perusahaan begitu canggihnya. Karyawan merupakaan kekayaan utama suatu perusahaan, karena tanpa keikutsertaan mereka, aktivitas perusahaan tidak akan terjadi. Karyawan berperan aktif dalam mencapai tujuan perusahaan (Hasibuan, 2005).

Semua perusahaan pasti mengiginkan karyawan memiliki pengabdian dan kesetiaan serta memberikan yang terbaik di dalam setiap pekerjaan yang mereka kerjakan. Tetapi untuk mempertahankan suatu tekad pengabdian sangat tidaklah mudah. Oleh karena itu, perusahaan harus mampu mempertahankan karyawan karena karyawan adalah salah satu aset internal yang paling berharga (Fahmi, 2013). Berikut ini terdapat berberapa kasus yang dapat memperlihatkan kepada kita tentang kurangnya tekad pengabdian yang dimiliki oleh karyawan.

Kasus berikut ini berhubungan dengan perilaku karyawan yang tidak menunjukan pengabdian terhadap perusahaan. Salah satunya terjadidi negara India lebih tepatnya di kota New Delhi pada 12 Januari 2015. Dimana terdapat seorang karyawan di Teknisi Eksekutif di Central Public Works Department yang memilih bolos kerja selama 24 tahun. Karyawan tersebut terus memperpanjang cutinya dan hanya datang untuk mengisi absen kerja. Namun, pada akhirnya karyawan tersebut dipecat karena diketahui oleh kementerian terkait di negara karyawan tersebut bekerja (www.bisnis.liputan6.com).

Selanjutnya, kasus lainnya terjadi pada tanggal 06 April 2015 yang berawal ketika mantan karyawan PT.Gunung Himun Pratam yang berinisial EH diangkat sebagai service coodinator sejak 1 mei 2009. Lalu, pada maret 2010 PT.Gunung Himun Pratama memperkuat hubungan hukum dengan EH melalui sebuah perjanjian kerjasama dimana 
dalam perjanjian kerjasama tersebut tertulis bahwa apabila EH mengundurkan diri maka dia dilarang untuk mendirikan usaha dan atau bekerja pada perusahaan yang sejenis, selama enam bulan sejak waktu pengunduran diri. Masalah kemudian timbul pada 1 Juli 2014 EH bekerja untuk PT.Tunggal Sejahtera Margawi yang merupakaan kompetitor. PT. Gunung Himun Pratama meminta agar majelis hakim Pengadilan Negeri Jakarta Selatan untuk memutuskan hubungan kerja EH dan PT. Tri Tunggal Sejahtera Margawi yang dianggap sebagai kompetitor dari PT.Gunung Himun Pratama. Selain itu, EH juga tergugat dihukum membayar RP 30.000.000 sebagai ganti rugi materil dan RP 100.000.000 sebagai ganti rugi (www.hukumonline.com).

Selanjutnya, kasus lainnya terjadi pada tanggal 16 Februari 2017 di perusahaan Google California pada divisi Wayno yang mengerjakan proyek mobil otomatis tanpa supir. Dimana karyawan pada divisi tersebut lebih memilih untuk resign dari perusahaan tersebut karena memiliki gaji 16 kali lipat dan pundi-pundi hingga jutaan dolar. Dengan gaji yang besar tersebut beberapa karyawan memilih keluar dari perusahaan untuk membangun startup atau perusahaan baru (techno.okezone.com).

Sama seperti kasus di atas, peneliti juga melakukan observasi dan wawancara di salah satu perusahaan retail sepeda motor di kota Medan Sumatera Utara, yaitu PT. Indako Trading Coy cabang Medan yang cukup terlihat banyak karyawan tetap pada perusahaan tersebut yang kurang memiliki pengabdian terhadap perusahaan tersebut. Hal itu terlihat dari tingginya tingkat turnover karyawan yang terjadi pada perusahaan tersebut pada tahun 2017 yang memperlihatkan bahwa karyawan pada PT. Indako Trading Coy cabang Medan tersebut kurang memiliki pengabdian terhadap perusahaan. Selain itu, peneliti juga melihat kurangnya kesadaran dari karyawan di PT. Indako Trading Coy cabang Medan tersebut untuk menaati dan patuh terhadap peraturan di perusahaan tersebut, seperti tingkat keterlambatan yang cukup tinggi yang terjadi pada karyawan, mendengarkan musik pada saat bekerja, memakai sandal pada saat berada di dalam kantor, bermain game pada saat bekerja, dan berberapa dari karyawan tersebut tidak memakai nametag yang telah disediakan oleh perusahaan tersebut.

Selain itu, karyawan tetap di perusahaan tersebut terlihat kurang bertanggung jawab untuk menyelesaikan pekerjaan yang telah diberikan dan lebih memilih meninggalkan pekerjaan yang belum selesai tersebut. Beberapa karyawan tetap pada PT. Indako Trading Coy cabang Medan kurang jujur yang terlihat dari tidak ada 
keselarasan antara apa yang terucap dengan kenyataannya, seperti pada salah satu karyawan yang meminta izin kepada atasan untuk keluar menyelesaikan tugas yang berhubungan dengan pekerjaannya tetapi kenyatannya karyawan tersebut pergi ke tempat lain.

Contoh kasus di atas, seperti bolos kerja, tidak patuh terhadap peraturan, tingkat keterlambatan yang cukup tinggi yang terjadi pada karyawan, mendengarkan musik pada saat bekerja, memakai sandal pada saat berada di dalam kantor, bermain game pada saat bekerja, dan serta tingginya tingkat turnover di perusahaan tersebut, merupakaan cerminan bahwa tidak ada loyalitas yang dimiliki oleh karyawan tersebut terhadap perusahaan. Menurut Sudarsana (2016) loyalitas karyawan adalah suatu sikap kesetiaan atau kepatuhan karyawan terhadap perusahaan dengan memiliki sikap komitmen atau kesediaan terhadap perusahaan tempatnya bekerja, dengan demikian yang menjadi pengukuran loyalitas terhadap karyawan adalah lamanya mereka bertahan dan memiliki dampak produktivitas yang lebih baik terhadap perusahaan.

Loyalitas adalah merupakan tekad dan kesanggupan untuk menaati, melaksanakan dan mengamalkan sesuatu yang ditaati dengan penuh kesadaran dan tanggung jawab (Flippo,1996). Senada dengan itu menurut Sastrohadiwiryo (2002) menyebutkan bahwa loyalitas karyawan adalah suatu tekad dan kesanggupan dari individu atau karyawan untuk menaati, melaksanakan, mengamalkan peraturan-peraturan yang ada di perusahaan dengan penuh kesadaran dan sikap tanggung jawab serta tidak adanya keterpaksaan dalam bekerja secara keseluruhan.

Loyalitas yang dimiliki oleh karyawan terhadap suatu perusahaan cenderung di pengaruhi oleh kualitas kehidupan kerja. Loyalitas karyawan dan kualitas kehidupan kerja memiliki hubungan antara satu dengan yang lainnya. Hal ini didukung oleh pendapat dari Heskeet., dkk (2008) menyatakan bahwa kualitas kehidupan kerja mempengaruhi kepuasaan dan loyalitas karyawan di dalam suatu perusahaan. Kualitas kehidupan kerja termasuk di dalamnya keadilan seorang pemimpin, kesempatan untuk bekerja sama, kesempatan untuk mengembangkan diri, dan mendapatkan kompensasi yang wajar. Senada dengan hal tersebut menurut program kualitas kehidupan kerja berkontribusi terhadap motivasi kerja karyawan, performance kerja, loyalitas karyawan, komitmen terhadap organisasi, rendahnya tingkat turnover, mengurangi 
absen karyawan, mengurangi perselisihan antar manajemen dan karyawan (Cartwright dalam Land.,dkk 2012).

Menurut Cascio (2003) menyebutkan bahwa yang dinamakan dengan kualitas kehidupan kerja adalah persepsi karyawan dimana karyawan menginginkan rasa aman, kepuasaaan, dan kesempatan untuk berkarya dan berkembang layaknya manusia. Selain itu menurut Robbins (2002) menyebutkan kualitas kehidupan kerja menggambarkan suatu proses bagaimana suatu organisasi merespon kebutuhan karyawan dengan cara mengembangkan mekanisme sedemikian rupa, sehingga para karyawan tersebut memiliki kesempatan membuat keputusan untuk merancang kehidupannya di dalam lingkup pekerjaan.

Masalah yang dipilih dipandang layak untuk diteliti karena beberapa alasan yaitu semakin rendahnya loyalitas pada karyawan dan karyawati PT. Indako Trading Coy Medan. Tujuan penulisan artikel ini adalah mengetahui dan menganalisis hubungan antara kualitas kehidupan kerja dengan loyalitas karyawan pada karyawan dan karyawati PT.Indako Trading Coy di Medan.

\section{METODE PENELITIAN}

Adapun variabel - variabel yang digunakan dalam penelitian adalah kualitas kehidupan kerja sebagai variabel bebas dan loyalitas karyawan sebagai variabel tergantung. Subjek dalam penelitian ini adalah karyawan dan karyawati di PT. Indako Trading Coy Medan. Jumlah subjek yang diambil dalam penelitian ini adalah 105 orang. Jumlah subjek tersebut diambil dengan metode Purposive Sampling yang merupakaan metode penetapan responden untuk dijadikan sampel berdasarkan pada kriteria. Adapun kriteria dari penetapan subjek adalah karyawan dan karyawati tetap di PT. Indako Trading Coy yang telah bekerja di perusahaan tersebut minimal 1 tahun, karyawan yang telah berusia minimal 2 tahun, karyawan dan karyawati pada level officer dan level supervisor.

Teknik pengumpulan data yang digunakan dalam penelitian ini dengan menggunakan teknik pembagiaan skala dimana terdapat pembagian skala untuk mengukur kualitas kehidupan kerja terhadap loyalitas karyawan. Jenis skala yang digunakan adalah skala Likert. Dengan skala Likert, maka variabel yang akan diukur dijabarkan menjadi indikator variabel. Kemudian indikator atau komponen-komponen 
Vol 2, No. 1, Agustus 2019: 12 -23, DOI: 10.34007/jehss.v2i1.47

tersebut dijadikan titik tolak untuk menyusun aitem-aitem instrument yang berupa pertanyaan atau pernyataa. Skala yang digunakan dalam penelitian ini menggunakan empat alternatif jawaban, yaitu SS (sangat sesuai), S (sesuai), TS (tidak sesuai), dan STS (sangat tidak sesuai), yang mana pernyataan favourable maka mengandung nilai-nilai yang positif, dengan pilihan jawabanSS (sangat sesuai) diberikan bobot 4 (empat), $\mathrm{S}$ (sesuai) dengan bobot 3 (tiga), TS (tidak sesuai) dengan bobot 2 (dua), dan STS (sangat tidak sesuai) dengan bobot 1 (satu). Sistem penilaian sebaliknya, jika pernyataan unfavourable, dengan pilihan jawabannyayaitu SS (sangat sesuai) diberikan bobot 1 (satu), S (sesuai) dengan bobot 2 (dua), TS (tidak sesuai) dengan bobot 3 (tiga), dan STS (sangat tidak sesuai) dengan bobot 4 (empat).

Teknik analisis yang digunakan untuk menganalisis data hasil penelitian ini adalah teknik korelasi Product Moment dari Pearson dengan menggunakan program SPSS 17 for windows. Sebelum data-data yang terkumpul dianalisa, terlebih dahulu dilakukan uji normalitas dan uji Linieritas.

\section{HASIL DAN PEMBAHASAN}

Berdasarkan penelitian yang telah dilakukan, maka diperoleh hasil bahwa ada hubungan positif antara kualitas kehidupan kerja dengan loyalitas karyawan dengan koefisien korelasi Product Moment (Pearson Correlation) sebesar 0,626 dan nilai p sebesar 0,000 ( $<<0,05)$. Berdasarkan nilai tersebut, artinya semakin tinggi kualitas kehidupan kerja yang dimiliki seorang individu, maka semakin tinggi loyalitas karyawan yang ada pada dirinya, dan sebaliknya semakin rendah kualitas kehidupan kerja yang dimiliki seorang individu, maka semakin rendah loyalitas karyawan yang dimiliki oleh individu tersebut.

Pada penelitian ini diperoleh koefisien determinasi $R$ Square $\left(\mathrm{R}^{2}\right)$ sebesar 0,392. Berdasarkan hasil tersebut, dapat disimpulkan bahwa 39,2 persen kualitas kehidupan kerja mempengaruhi loyalitas karyawan di PT. Indako Trading Coy, sedangkan 60,8 persen dipengaruhi oleh faktor lain. Adapun faktor lain yang turut mempengaruhi loyalitas karyawan seorang individu diantaranya seperti Beban Kerja, Pengembangan Karir, Kompensasi, Lingkungan kerja..

Hasil penelitian ini didukung oleh pendapat dari Heskeet., dkk (2008) menyatakan bahwa kualitas kehidupan kerja mempengaruhi kepuasaan dan loyalitas karyawan di 
dalam suatu perusahaan. Kualitas kehidupan kerja termasuk di dalamnya keadilan seorang pemimpin, kesempatan untuk bekerja sama, kesempatan untuk mengembangkan diri, dan mendapatkan kompensasi yang wajar. Senada dengan hal tersebut menurut program kualitas kehidupan kerja berkontribusi terhadap motivasi kerja karyawan, performance kerja, loyalitas karyawan, komitmen terhadap organisasi, rendahnya tingkat turnover, mengurangi absen karyawan, mengurangi perselisihan antar manajemen dan karyawan (Cartwright dalam Land.,dkk 2012).

Selain itu, penelitian yang dilakukan oleh Afrizal.,dkk (2012) terhadap 60 orang karyawan PT. Bank Aceh, cabang Bener Meriah. Hasil penelitian menunjukan bahwa ada hubungan positif yang signifikan antara kualitas kehidupan kerja dengan loyalitas karyawan, karena kualitas kehidupan kerja mengacu pada suatu keadaan dimana kebutuhan yang dimilliki karyawan dalam suatu perusahaan dapat terpenuhi dan sejauh mana perusahaan dapat berkontribusi dalam memenuhi hak-hak karyawan yang sesuai dengan standar yang berlaku. Sehingga semakin tinggi kualitas kehidupan kerja, maka semakin tinggi pula loyalitas karyawan di dalam suatu perusahaan.

Adapun penelitian ini menunjukkan rata-rata subjek penelitian yang terdapat dalam memiliki loyalitas karyawan yang sedang dapat terlihat dari data penelitian terdapat 71 individu dengan persentase 67,62 persen berada pada kategori sedang, kemudian 32 individu dikategorikan memiliki loyalitas karyawan tinggi dengan persentase sebesar 30,48 persen dan terdapat 2 individu dikategorikan memiliki loyalitas rendah dengan presentase sebesar 1,9 persen. Berdasarkan penjelasan diatas dapat disimpulkan rata-rata karyawan dan karyawati di PT.Indako Trading Coy memiliki loyalitas karyawan yang sedang atau menengah.

Berdasarkan hasil kategorisasi, observasi dan wawancara terhadap karyawan dan karyawati pada PT.Indako Trading Coy, menunjukkan bahwa loyalitas karyawan yang termasuk dalam kategori tinggi yaitu 32 orang atau 30,48 persen dari keseluruhan subjek penelitian, terlihat karyawan dan karyawati yang memiliki kategori tinggi tersebut menaati dan mematuhi peraturan yang terdapat di perusahaan tersebut tanpa merasa sedikitpun terbeban dengan peraturan-peraturan yang ditetapkan oleh perusahaan. Menyelesaikan tanggung jawab yang diberikan oleh atasan kepadanya sampai selesai bahkan melebihi jam bekerja yang telah ditetapkan oleh perusahaan. Subjek juga menyatakan bahwa tidak jarang ia menyelesaikan pekerjaan dan tanggung 
jawab yang belum selesai tersebut pada saat hari libur. Para subjek tersebut juga selalu menaati dan melakukan perjalanan dinas yang diperintahkan kepada subjek tersebut, subjek tersebut juga melakukan bukti perjalanan dinas melalui sebuah memo yang diberikan kepada atasan mereka sebagai bukti dari perjalanan dinas mereka.

Selain itu berdasarkan hasil kategorisasi dan wawancara terhadap 71 orang atau 67,62 persen subjek penelitian dengan tingkat kategori loyalitas karyawan yang sedang, menunjukkan bahwa adanya para beberapa subjek melanggar beberapa peraturan yang telah ditetapkan oleh perusahaan apabila tidak diawasi oleh atasan mereka dan mengikuti karyawan yang lain apabila mereka juga melanggar peraturan tersebut seperti memakai sandal pada saat jam bekerja, tidak memakai nametag di lingkungan pekerjaan, dan makan siang pada saat jam kerja. Namun, apabila mereka sedang diawasi oleh atasan mereka dan apabila dari pihak Human Resource Department melakukan razia, para subjek akan mematuhi peraturan yang terdapat di perusahaan. Beberapa dari para subjek juga mengaku bahwa mereka juga sering mengerjakan tugas kuliah pada saat jam kerja dengan alasan tidak sempat apabila mereka mengerjakan tugas rumah tersebut di rumah mereka. Ketika ditanyakan, beberapa subjek juga mengakui bahwa mereka sering berbohong kepada atasan mereka untuk ijin dari kantor dengan alasan pekerjaan, padahal mereka pergi ke tempat lain yang sama sekali tidak berhubungan dengan pekerjaan mereka, seperti mengunjungi wisuda kerabat dekat, mengunjungi bazaar event.

Selain itu berdasarkan hasil kategorisasi dan wawancara terhadap 2 orang atau 1,9 persen subjek penelitian dengan tingkat kategori loyalitas karyawan yang rendah adalah 2 (orang) karyawan yang sudah mendapatkan surat peringatan yang diberikan oleh perusahaan kepada 2 orang subjek tersebut. Subjek tersebut kerap kali melanggar peraturan yang telah ditetapkan oleh perusahaan seperti tingkat keterlambatan yang tinggi, keluar dari lingkungan kantor pada saat jam kerja, tidak memakai pakaian seperti yang telah ditetapkan oleh perusahaan, tidak memakai nametag, bermain handphone pada saat jam bekerja, tidak melaksanakan tanggung jawab yang telah diberikan oleh atasan kepadanya.

Akibat hal tersebut, subjek tersebut sudah sering di mutasi oleh perusahaan karena kurangnya tanggung jawab yang diberikan atasan kepadanya. Subjek tersebut juga pernah mendapatkan kasus dimana subjek meminta ijin untuk mengurusi hal-hal 
yang berkaitan dengan pekerjaannya, akan tetapi subjek tersebut pergi ke bioskop di salah satu mall di Kota Medan. Ketika ditanyakan, ia menceritakan bahwa subjek sengaja berperilaku seperti itu karena subjek sangat mengharapkan adanya pemecatan yang dilakukan oleh perusahaan terhadap dia, sehingga perussahaan akan memberikan pesangon kepada dia.

Penelitian ini juga menunjukkan rata-rata karyawan dan karyawati di PT. Indako Trading Coy memiliki kualitas kehidupan kerja yang termasuk dalam kategori sedang yaitu 77 individu atau sebesar 73,33 persen, 16 subjek atau 15,24 persen dikategorikan memiliki kualitas kehidupan kerja tinggi dan 12 subjek atau 11,43 persen yang memiliki kualitas kehidupan kerja yang rendah. Berdasarkan penjelasan diatas dapat disimpulkan rata-rata karyawan dan karyawati di PT. Indako Trading Coy memiliki tingkat kualitas kehidupan kerja yang termasuk dalam kategori sedang.

Berdasarkan kategorisasi, hasil observasi dan wawancara terhadap karyawan dan karyawati pada PT. Indako Trading Coy terungkap bahwa rata-rata individu memiliki kualitas kehidupan kerja yang tinggi yaitu 16 subjek atau 15,24 persen. Penuturan beberapa individu mengatakan bahwa mereka merasa bahwa kompensasi yang diberikan oleh perusahaan kepada mereka sudah lebih dari cukup dengan beban kerja yang diberikan kepadanya. Mereka juga berpendapat bahwa lingkungan kerja di perusahaan cukup aman dan sehat juga tidak membawa dampak yang negatif terhadap kesehatan secara fisik mereka, para subjek juga merasa aman dan nyaman sehingga para subjek merasa dapat memberikan yang terbaik bagi perusahaan.

Para atasan dari subjek tersebut juga kerap memberikan tanggung jawab ataupun melibatkan para subjek untuk mengambil beberapa keputusan untuk perusahaan kedepannya, sehingga membuat para subjek merasa sangat dihargai dan membuat ia menjadi lebih berkembang. Terkadang mereka juga merenungkan bahwa selama perusahaan masih memberikan hak-hak karyawan yang semestinya, maka para subjek tersebut juga bersyukur dengan bekerja di perusahaan tersebut.

Berdasarkan hasil kategorisasi dan wawancara kepada 77 subjek atau 73,33 persen individu yang memiliki tingkat kualitas kehidupan kerja menengah mengungkap bahwa adanya individu yang terkadang masih merasa tidak puas dengan kompensasi yang diberikan oleh perusahaan kepadanya, padahal para subjek merasa sudah memberikan yang terbaik bagi perusahaan. Namun beberapa subjek menjelaskan 
Vol 2, No. 1, Agustus 2019: 12 -23, DOI: 10.34007/jehss.v2i1.47

bahwa karena terbatasnya lapangan pekerjaan atau ada beberapa subjek yang sedang menempuh pendidikan yang lebih tinggi sehingga membuat beberapa subjek untuk memilih bertahan dan mencoba untuk mensyukuri kompenasi yang telah di berikan oleh perusahaan kepadanya.

Para subjek juga menjelaskan bahwa merasa peluang yang terbatas untuk merasa tumbuh bagi mereka dimana para atasan jarang melibatkan mereka dalam pengambilan keputusan ataupun memberikan tanggung jawab yang lebih kepada mereka sehingga mereka hanya melakukan aktivitas atau pekerjaan yang sama setiap harinya. Terkadang mereka menginginkan bahwa mereka dapat melakukan hal-hal atau suatu pekerjaan yang baru sehingga dapat membuat mereka lebih dapat berkembang.

Berdasarkan hasil kategorisasi wawancara terhadap 12 orang subjek atau 11,43 persen individu yang memiliki tingkat kualitas kehidupan kerja yang rendah, diketahui bahwa dirinya merupakan para subjek yang sangat tidak puas dengan kompensasi yang diberikan oleh perusahaan kepadanya, sehingga para subjek tersebut memiliki keinginan yang kuat untuk bekerja di perusahaan lain yang memberikan kompensasi yang lebih layak kepada mereka. Para subjek juga mengeluh tentang perusahaan yang kurang memperhatikan hak-hak karyawan seperti mereka seperti tidak diberikannya slip gaji per bulannya, uang lembur yang tidak diberikan kepada beberapa subjek tersebut dimana perusahaan atau atasan mereka selalu menuntut mereka untuk bekerja dengan cara loyalitas.

Berdasarkan penjelasan di atas dapat disimpulkan bahwa tinggi atau rendahnya nilai kualitas kehidupan kerja yang dimiliki oleh karyawan dan karyawati di PT.Indako Trading Coy, dapat membantu diri mereka dalam mendapatkan loyalitas karyawan di dalam suatu perusahaan. Merujuk dari pemaparan tersebut, maka dapat dikatakan bahwa ada hubungan positif antara kualitas kehidupan kerja dengan loyalitas karyawan yang dimiliki oleh karyawan dan karyawati. Artinya, semakin tinggi tingkat kualitas kehidupan kerja yang dimiliki seorang individu, maka semakin tinggi pula loyalitas karyawan yang dimiliki oleh individu tersebut. Sebaliknya, semakin rendah tingkat kualitas kehidupan kerja yang dimiliki para karyawan dan karyawati di PT. Indako Trading Coy, maka semakin rendah pula loyalitas karyawan yang ada pada diri mereka. 


\section{SIMPULAN}

Ada hubungan positif antara kualitas kehidupan kerja dengan loyalitas karyawan pada karyawan dan karywati di PT.Indako Trading Coy Medan dengan korelasi Product Moment (r) sebesar 0,626 dengan p sebesar 0,000 ( $<<0,05)$, artinya semakin tinggi kualitas kehidupan kerja maka semakin tinggi juga loyalitas karyawan, sebaliknya jika semakin rendah kualitas kehidupan kerja, maka semakin rendah pula loyalitas karyawan. Mean empirik dari loyalitas karyawan pada karyawan dan karyawati pada PT. Indako Trading Coy Medan secara keseluruhan menunjukkan bahwa loyalitas karyawan subjek penelitian tinggi yang dilihat dari mean empirik sebesar 91,91 lebih besar daripada nilai mean hipotetik sebesar 82,5. Berdasarkan kategori, maka dapat dilihat bahwa 32 orang atau 30,48 persen memiliki loyalitas karyawan yang tinggi, 71 orang atau 67,62 persen subjek memiliki loyalitas karyawan sedang, dan 2 orang atau 1,9 persen subjek yang memiliki loyalitas karyawan rendah. Mean dari kualitas kehidupan kerja pada karyawan dan karyawati pada PT. Indako Trading Coy Medan secara keseluruhan menunjukkan bahwa kualitas kehidupan kerja subjek penelitian tinggi. Dilihat dari nilai mean empirik sebesar 95,47 lebih besar dari mean hipotetik sebesar 95. Berdasarkan kategori, maka dapat dilihat bahwa sebanyak 16 orang atau 15,24 persen memiliki kualitas kehidupan kerja yang tinggi dan 77 orang atau 73.33 persen memiliki kualitas kehidupan kerja yang sedang dan 12 orang atau 11,43 persen yang memiliki kualitas kehidupan kerja yang rendah. Hasil penelitian ini menunjukkan bahwa sumbangan efektif yang diberikan variabel kualitas kehidupan kerja terhadap loyalitas karyawan adalah sebesar 39,2 persen, selebihnya 60,8 persen dipengaruhi faktor lain yang tidak diteliti seperti beban kerja, pengembangan karir, komnpensasi, dan lingkungan kerja

\section{DAFTAR PUSTAKA}

Afrizal., Aziz. N., \& Yunus. M. (2012). Pengaruh Kualitas Kehiduapan Kerja(Quality of Work Life), dan Kompensasi Terhadap Loyalitas serta Dampaknya Pada Kinerja Karyawan PT. Bank Aceh Cabang Bener Meriah. Jurnal Ilmu Manajemen Vol.1 No.1 hal 1-18.

Cascio, W.F. (2003). Manajemen Sumber Daya Manusia. Cetakan Ketujuh. Jakarta: Erlangga

Fahmi,I . (2013). Perilaku Organisasi.Bandung: Alfabeta.

Flippo, E. B. (1996). Manajemen Personalia. Jakarta: Erlangga

Hasibuan, M.S.P. (2005). Manajemen Sumber Daya Manusia (Edisi Revisi). Jakarta : Bumi Aksara.

Heskett, J. L., Sasser, W.E., \& Wheeler. J. (2008). The Ownership Quotient Putting the Service Profit Chain to Work for Unbeatable Competitive Advantage. USA : Harvard Bussiness Press

Land, K. C., Michalos, A. C., \& Sirgy, W. J. (2012). Handbook of Social Indicators and Quality of Life Research. New York : Springer Publishing Company. 
Vol 2, No. 1, Agustus 2019: 12 -23, DOI: 10.34007/jehss.v2i1.47

Robbins, S. P. (2002). Prinsip-prinsip Perilaku Organisasi Edisi Kelima. Penerjemah $\quad$ : Halida dan Dewi Sartika. Jakarta: Erlangga.

Sastrohadiwiryo, S. B. (2002). Managemen Tenaga Kerja Indonesia Pendekatan Administratif dan Operasional. Jakarta: Bumi Aksara

Sutrisno, Edy. (2017). Manajemen Sumber daya Manusia. Cetakan ke-9. Jakarta: Kencana

Sudarsana. 2016.116 Kiat Mempertajam Kinerja Anak Buah. Bandung: Laksana

Fauzi, M.P.(2017, Februari). Punya gaji 16 kali lipat, karyawan Google pilih untuk resign. Di dari dari http://www.techno.okezone.com/read/2017/02/15/207/1619395/punya-gaji-16 kali-lipatkaryawan-google-pilih-untuk-resign.

Deil,S.A.F.(2015,Januari). Bolos kerja selama 24 tahun, karyawan ini akhirnya dipecat. Di undah dari http://m.liputan6.com/bisnis/read/2159409/bolos-kerja-selama-24-tahun-karyawan-iniakhirnya-dipecat

Ali.(2015, April). Pindah ke kompetitor, eks karyawan digugat perusahaan. Di unduh dari http://m.hukumonline.com/berita/baca/lt55224dcc4c1cb/pindah-ke- $\quad$ kompetitor--ekskaryawan-digugat-perusahaan 